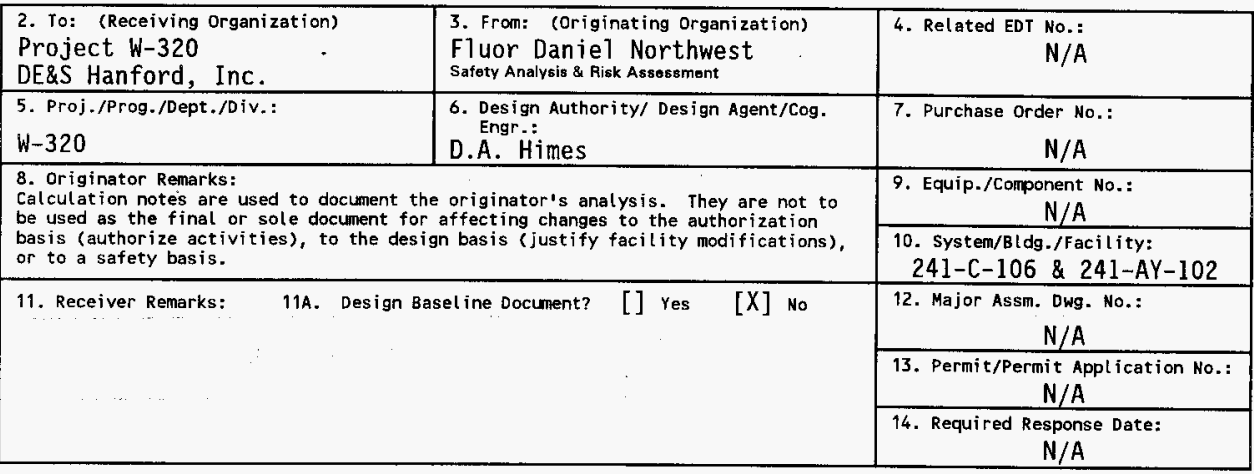

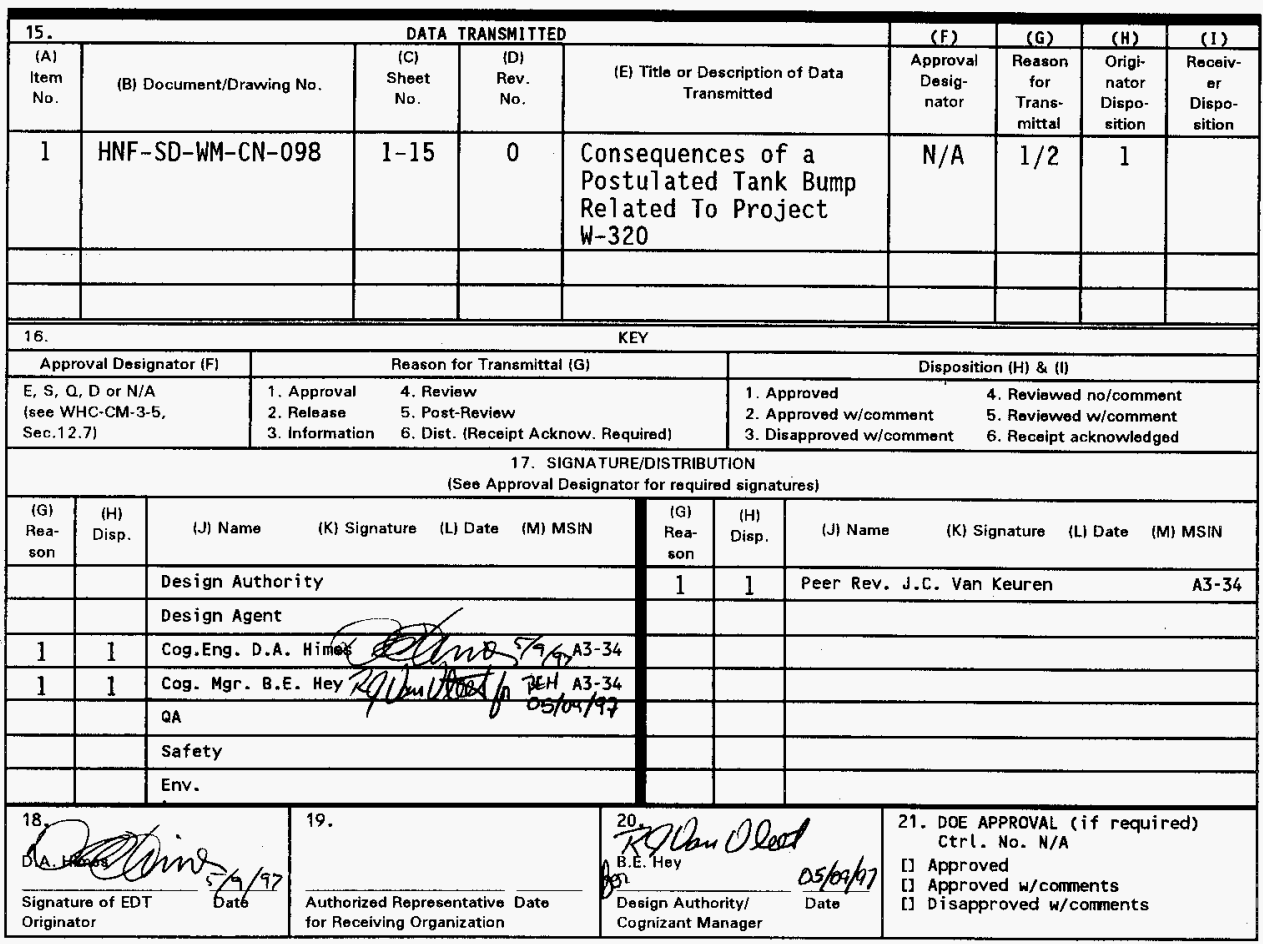

BD-7400-172-2(05/96) GEF097 


\section{Consequences of a Postulated Tank Bump Related To Project W-320}

\section{D.A. Himes}

Fluor Daniel Northwest Inc., Richland, WA 99352

U.S. Department of Energy Contract DE-AC06-96RL 13200

$$
\begin{array}{lll}
\text { EDT/ECN: } & 621232 & \text { UC: } 510 \\
\text { Org Code: } & 403 & \text { Charge Code: E09120/P3EU00 } \\
\text { B\&R Code: } & \text { EW3130010 } & \text { Total Pages: } 14 \text { gB } 15
\end{array}
$$

Key Words: Steam bump, Tank bump, $W-320$

Abstract: An analysis was performed of radiological and toxicological consequences of a conservative tank bump scenario which could occur if preventative measures fail and the local sludge temperature exceed the saturation temperature for a long enough period of time to produce a release of this type. Because of the nature of the release, there are no effective mitigative actions which can be taken other than prevention of the tank bump. The unmitigated scenario analyzed here exceeded both onsite and offsite risk guidelines for an anticipated accident.

\footnotetext{
TRADEMARK DISCLAIMER. Reference herein to any specific commercial product, process, or service by trade name, trademark, manufacturer, or otherwise, does not necessarily constitute or imply its endorsement, recommendation, or favoring by the United States Government or any agency thereof or its contractors or subcontractors.

Printed in the United States of America. To obtain copies of this document, contact: Document Control Services, P.O. Box 950, Mailstop H6-08, Richland WA 99352, Phone (509) 372-2420; Fax (509) 376-4989.
}
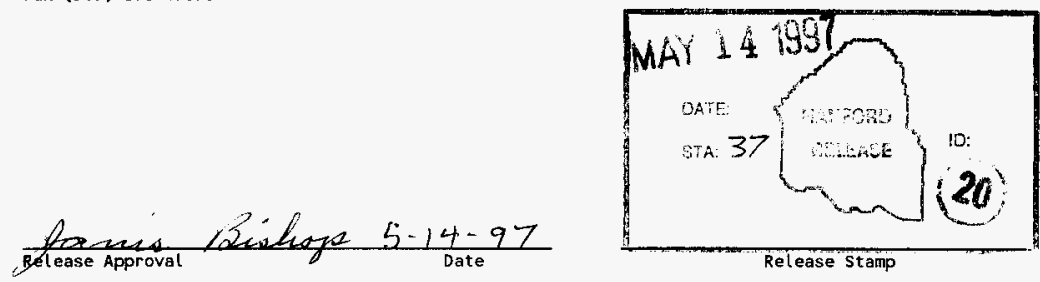

\section{Approved for Public Release}


HNF-SD-WM-CN-098 Rev. 0

\title{
CONSEQUENCES OF A POSTULATED TANK BUMP RELATED TO PROJECT $W-320$
}

\author{
D.A. Himes \\ $3 / 18 / 97$
}

The purpose of Project $W-320$ is to retrieve part or all of the soft sludge from Tank 241-C-106 by sluicing it with supernate pumped from Tank 241-AY-102 and pumping the suspended sludge back to Tank 241-AY-102 (Sathyanarayana 1996). Tank 24l-C-106 is a single-shell tank (SST) containing 197,000 gallons (about 69 inches) of soft sludge with a total heat load estimated at 132,400 $\mathrm{Btu} / \mathrm{h}$ (as of June 1994). This tank is on the High Heat Watch List and must have periodic water additions to maintain the waste temperatures within allowable limits by means of evaporative cooling using active ventilation. Tank 241-AY-102 is a double-shell tank (DST) with a sludge layer about 12 inches thick $(32,000$ gallons) and 812,000 gallons of supernate for a total waste depth of about 30 feet. The estimated heat load of Tank 241-AY-102 is $33,000 \mathrm{Btu} / \mathrm{h}$ (as of February 1995). The immediate goal of the project is to eliminate the need for continued water addition to Tank 241-C-106.

If the local temperature in the sludge layer of a waste tank reaches the saturation temperature at that location for the intersticial solution at the local hydrostatic pressure, the void fraction of the sludge will begin to increase due to steam formation. This will decrease the local density of the sludge and produce an increasing buoyant force as the void fraction increases. This al so creates a thermal runaway condition since the increasing void fraction will decrease the thermal conductivity of the sludge causing the temperature to rise faster. At some point the buoyant forces will exceed the mechanical strength of the sludge layer and a steam plume will break out of the sludge and rise toward the surface of the supernate layer. If the supernate layer is cool enough, rapid condensation of the rising steam plume can occur, and the plume may never reach the surface of the supernate layer. In more severe cases, however, the steam plume may have sufficient size and energy content to break through the surface of the waste and pressurize the head space. This type of event (commonly referred to as a "tank bump") can have severe consequences due to entrainment of solids and liquids within the steam plume, and possible failure of the tank ventilation system HEPA filters along with back flow through pit drain lines and other openings, thereby producing an energetic unfiltered release of tank waste to the environment.

Tank bumps have been reported in the mid-1950s in aging waste tanks. Some of these incidents have produced radioactive contamination of the immediate surroundings. Current heat loads in the tanks and the operation of active ventilation systems have virtually eliminated the possibility of a tank bump under normal operating conditions. A tank bump could still occur, however, if operations related to the tanks produce any of the following conditions without compensating measures being taken: 
HNF-SD-WM-CN-098 Rev. 0

1. Removal of material from a tank so as to reduce the hydrostatic pressure within the sludge layer and, hence decrease the saturation temperature of the intersticial solution;

2. Increasing the heat load in a tank by adding material;

3. "Fluffing" the sludge layer to a greater thickness so as to increase the heat transfer distances for heat removal; or

4. Providing inadequate cooling of the tank for an extended period.

All of the first three conditions will occur during the transfer of material from Tank 241-C-106 to Tank 241-AY-102. The fourth condition could occur due to ventilation system failure, improper switching between ventilation modes during the transfer, or a mistake in the real time calculations and simulations used to $\mathrm{plan}$ operating mode changes during the sludge transfer operations. In addition, the presence of an organic oil film on the top of the supernate layer, if present, could impede evaporative cooling of the tank, and the presence of any radiolytic or organic decomposition gas in the sludge layer could decrease the thermal conductivity of the sludge. Either of these conditions, if they develop, could raise sludge temperatures and thereby decrease the safety margin.

Initial cooling of the tank contents, along with careful planning of transfer increments and intermediate cooling periods will be needed, and are planned, to maintain the maximum sludge temperatures in both tanks well below the local saturation temperatures at all times during the operation. These measures will, of course, be augmented by full use of the in-tank instrumentation and use of ongoing computer simulations to project tank temperature profiles. The mitigation of the tank bump accident therefore consists of preventing the event thereby ensuring no consequent releases.

The purpose of this document is to present an analysis of radiological and toxicological consequences of a conservative tank bump scenario which could occur if preventative measures fail and the local sludge temperature exceeded the saturation temperature for a long enough period of time to produce a release of this type. Because of the nature of the release, there are no effective mitigative actions which can be taken other than prevention of the tank bump. The scenario analyzed here can therefore be regarded as the unmitigated tank bump accident for this operation.

Description of Operation:

The saturation temperature in the sludge in Tank 241-C-106 will decrease by about $1.1^{\circ} \mathrm{C}\left(2^{\circ} \mathrm{F}\right)$ for every foot of waste removed from the tank (Bander 1996). This effect is immediate upon removal of any waste from the tank. The effect of cooling the surface of the waste, however, is very gradual over some period of time (at least several weeks). Prior to the start of sluicing operations, therefore, the tank contents will be cooled for some period of time by 


\section{HNF-SD-WM-CN-098 Rev. 0}

chilling the ventilation intake air to less than $4.4^{\circ} \mathrm{C}\left(40^{\circ} \mathrm{F}\right)$. A layer of cooling water about 1 foot deep is maintained at all times on top of the sludge layer to provide evaporative cooling and to keep the sludge wet.

During the sludge transfer operation, the variable-speed slurry pump in Tank 241-C-106 will take a suction in the sludge layer and direct the slurry to a distribution head above the sludge layer in Tank 241-AY-102. At the same time, the sluice pump in Tank 24l-AY-102 will take a suction near the top of the supernate layer and direct a flow of about $350 \mathrm{gpm}$ to the sluice nozzle in Tank 241-C-106 which will discharge above the waste, but below the top of the tank liner. The sluicing nozzle will be remotely viewed and operated from the control room so as to break up the sludge and direct it toward the slurry pump intake. Thermal analysis (Bander 1996) indicates that incremental removal of the sludge (about $2 \mathrm{ft}$ at a time) followed by cooling periods of 1 to 2 weeks should eliminate the possibility of a tank bump in 241-C-106.

The waste transferred into Tank 241-AY-102 will add to the heat load in the tank causing an increase in the sludge temperatures. In addition, the sludge from 241-C-106 will probably not settle back immediately to its original volume, but will initially remain "fluffed" to some greater volume and therefore depth. This increases the distance over which heat transfer must take place, and further increases the temperature in the sludge. At this point the amount of fluffing (the fluff factor) to be expected is uncertain. As a preliminary estimate based on past experience in other tanks, a fluff factor of 2 is being assumed. After an addition, the sludge temperatures will not reach their new steady-state values for some time (about 300 days for transfer of $2 \mathrm{ft}$ of sludge from 241-C-106) (Sathyanarayana 1997). Real-time temperature data on the tank contents will therefore have to be input in the form of an initial temperature history into a computer simulation in order to project what the final sludge temperature will be. The results will be used to plan cooling times and further sludge transfers.

Thermal analysis of Tank 241-AY-102 (Sathyanarayana 1997) indicates that only $2 \mathrm{ft}$ of sludge can be safely retrieved from Tank 24l-C-106 with the present secondary (annulus) ventilation system which provides $155 \mathrm{cfm}$ to the tank floor channels. Transfer of more than $2 \mathrm{ft}$ of sludge will require considerable modifications to the 241-AY-102 annulus ventilation system to provide adequate cooling through the bottom of the tank.

\section{Tank Bump Scenarios:}

In this operation, material will be removed from $C-106$ and added to $A Y-102$ so that a bump in $\mathrm{C}-106$ should be bounded by the existing tank farm safety documentation. A number of bump scenarios were analyzed using a 2-D computer simulation (Sathyanarayana 1996) and it was found that greater waste depth allowed a larger amount of energy to be accumulated in the sludge prior to an event, leading to more severe bumps with larger releases. A bump in C-106 was therefore assumed to be bounded by bumps analyzed for AY-102 in terms of release consequences. In addition, if a bump were to occur, the nature of the 
HNF-SD-WM-CN-098 Rev. 0

operation indicates a much higher likelihood for a bump in AY-102 than in c-106.

The following basic assumptions were made in the analyses of the scenarios considered here (Sathyanarayana 1996):

1. A total of $4.75 \mathrm{ft}$ of sludge was assumed to have been transferred from C-106 to AY-102 producing a total sludge depth of $11 \mathrm{ft}$ in AY-102 (fluff factor $=2$ ). The total pool depth was assumed to be maintained at $30 \mathrm{ft}$ at all times.

2. A "best estimate" temperature profile was assumed for the sludge layer corresponding to conditions leading to an initial bump due to inadequate cooling for the heat load.

3. Decreasing the resistance to leakage out of the tank head space will increase the severity of the bump and, in general, tend to increase the quantity of steam released. In the cases considered here, the vent configuration with the largest steam release was assumed since it maximized the consequences with regard to transportable, respirable releases.

4. It was assumed that there was essentially no slip between phases and no deposition in the system except settling in the tank waste following the release.

5. The sludge viscosity determines, in part, the ability of the sludge to trap steam bubbles and also determines the degree to which sludge at the saturation temperature is separated from subcooled sludge and supernate during a bump. A maximum viscosity of $80001 \mathrm{bm} / \mathrm{ft} \cdot \mathrm{s}(1.2 \mathrm{E}+7 \mathrm{cp})$ was assumed in these analyses for sludge having maximum volume fraction of particles.

6. A higher sludge yield strength will allow more energy to be stored in the sludge before the steam can break out of the sludge layer. However, a higher yield strength will also hold some sludge in place preventing it from participating in the bump. It was assumed that the net effect of the yield strength would be to reduce the magnitude of the bump, and so the sludge yield strength was assumed to be zero in these analyses.

7. The potential for the steam to condense and the sludge to cool before the steam can reach the surface of the pool increases as the supernate subcooling increases. Simulations were performed which neglected condensation (i.e., supernate at saturated conditions), and which included condensation in subcooled supernate. To take credit for condensation it would be required to establish the amount of subcooling in the supernate when the bump occurred. Condensation in the supernate layer was conservatively neglected in the scenarios used here. 
The tank bump simulations were based on $11 \mathrm{ft}$ of sludge in Tank 241-AY-102 with the properties of the consolidated waste of tank C-106 and tank AY-102. Parameters used in the analyses were as follows:

Tank:

Primary Tank Diameter

Secondary Tank Diameter

Tank Contents:

Undissolved (dry) Solids Density
Aqueous Solution Density
Sludge (1iquid-solid mixture) Density
Total Waste Depth
Supernatant (aqueous solution) Depth
Sludge (nonconvective 1ayer) Depth
Tank AY-102 Heat Load
Transferred C-106 Sludge Heat Load
Total Heat Load

Supernatant:
$75 \mathrm{ft}$

$80 \mathrm{ft}$

\author{
$113.91 \mathrm{bm} / \mathrm{ft}^{3}\left(1.82 \mathrm{~g} / \mathrm{cm}^{3}\right)$ \\ $75.51 \mathrm{bm} / \mathrm{ft}^{3}\left(1.21 \mathrm{~g} / \mathrm{cm}^{3}\right)$ \\ $81.21 \mathrm{bm} / \mathrm{ft}^{3}$ \\ $30 \mathrm{ft}$ \\ $19 \mathrm{ft}$ \\ $11 \mathrm{ft}$ \\ 33, $000 \mathrm{Btu} / \mathrm{hr}$ \\ $92,400 \mathrm{Btu} / \mathrm{hr}$ \\ $125,000 \mathrm{Btu} / \mathrm{hr}$
}

Heat Capacity

Thermal Conductivity

Heat Generation Rate
$0.8 \mathrm{Btu} / 1 \mathrm{bm} \cdot{ }^{\circ} \mathrm{F}$
$0.35 \mathrm{Btu} / \mathrm{hr} \cdot \mathrm{ft} \cdot{ }^{\circ} \mathrm{F}$
$0.0 \mathrm{Btu} / \mathrm{hr} \cdot 1 \mathrm{bm}$

Insoluble Solids:

\author{
Heat Capacity \\ Thermal Conductivity \\ Heat Generation Rate, Unwashed Waste \\ Particle Size, Washed Waste \\ Volume Fraction of Solids
}

\author{
$0.2 \mathrm{Btu} / 1 \mathrm{bm} \cdot{ }^{0} \mathrm{~F}$ \\ $5.0 \mathrm{Btu} / \mathrm{hr} \cdot \mathrm{ft} \cdot{ }^{\circ} \mathrm{F}$ \\ $0.1394 \mathrm{Btu} / \mathrm{hr} \cdot 1 \mathrm{bm}$ \\ 1 - $10 \mu \mathrm{m}$ range \\ $5 \mu \mathrm{m}$ average \\ $16.25 \%$
}

The transferred sludge thickness was based on the assumption that the sludge particles from tank $C-106$ will resettle to a particle concentration at least half as large as that which currently exists in that tank. The normal operation of tank $A Y-102$ with the consolidated sludge will require a primary ventilation flow of about $600 \mathrm{cfm}$ and a secondary flow of at least $2000 \mathrm{cfm}$ (or equivalent if intake air is chilled) in order to keep the maximum sludge temperatures below the OSR criteria. Insufficient cooling (especially in the tank floor channels) over a long period (months) can be expected to lead to a tank bump. Complete loss of floor cooling channel flow will cause the peak sludge temperatures to reach saturation values in about 60 days. 
HNF-SD-WM-CN-098 Rev. 0

\section{Atmospheric Transport:}

Receptor locations and atmospheric dispersion factors $\left(X / Q^{\prime}\right)$ were developed and are reported in WHC-SD-WM-SARR-016, Tank Waste Compositions and Atmospheric Dispersion Coefficients for Use in Safety Analysis Consequence Assessments (Van Keuren 1996a). For these short duration ground leve 1 releases the $<1$ hour $X / Q$ s are used. The reported values are $X / Q^{\prime}=3.41 E-2$ $\mathrm{s} / \mathrm{m}^{3}$ for the onsite receptor (at $100 \mathrm{~m}$ ) and $X / Q^{\prime}=2.83 E-5 \mathrm{~s} / \mathrm{m}^{3}$ for the offsite receptor (at the site boundary or the near bank of the Columbia River, whichever is closer). Note that for very short duration releases, these timeintegrated $X / Q$ s are used only for radiological doses. For toxicological exposures puff $X / Q$ s must by used which take into account dispersion in the direction of travel in order to obtain an accurate estimate of peak concentration as the plume passes the receptor. The puff $X / Q$ s are built into the unit release sums of fractions (SOF) developed in WHC-SD-WM-SARR-011, Toxic Chemical Considerations for Tank Farm Releases (Van Keuren 1996b) and do not need to be handled explicitly here.

\section{Consequence Methodology:}

Radiological and toxicological consequences of releases from the 200 Area Tank Farms were calculated using radiological dose and toxic exposure conversion factors developed in WHC-SD-WM-SARR-037, Development of Radiological Concentrations and Unit Liter Doses for TWRS FSAR Radiological Consequence Calculations (Cowley 1996) and WHC-SD-WM-SARR-011, Toxic Chemical Considerations for Tank Farm Releases (Van Keuren 1996b). Unit Liter Doses (ULD) for Tank 241-AY-102 solids and liquids are shown in Table 1. Inhalation and ingestion ULDs were taken from WHC-SD-WM-SARR-037 for AWF tanks.

Table 1: Unit Liter Doses (ULD) for Tank 241-AY-102 waste components

\begin{tabular}{|c|}
\hline ste Com \\
\hline
\end{tabular}

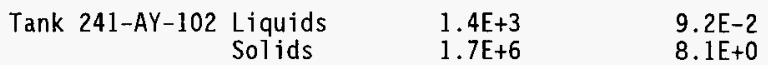

These ULDs were used to calculate onsite and offsite receptor radiological doses using the following formulas. All doses are 50-year committed effective dose equivalents (CEDE). Ingestion doses are for a 24-hour uptake period by the offsite receptor immediately after the passage of the plume assuming a 24 hour delay before evacuation and/or interdiction of food supplies. 
For onsite and offsite inhalation doses:

$$
D_{i n h}=(Q)\left(X / Q^{\prime}\right)(B R)\left(U L D_{i n h}\right)
$$

And for offsite ingestion doses:

$$
D_{\text {ing }}=(Q)\left(X / Q^{\prime}\right)\left(U L D_{\text {ing }}\right)
$$

Where

$$
\begin{aligned}
& D_{\text {inh }}=\text { inhalation dose (Sv) } \\
& D_{\text {ing }}=\text { ingestion dose (SV) } \\
& Q^{\prime}=\text { respirable release in terms of liters of waste material (L) } \\
& X / Q^{\prime}=\text { atmospheric dispersion coefficient }\left(\mathrm{s} / \mathrm{m}^{3}\right) \\
& B R=\text { receptor breathing rate }\left(\mathrm{m}^{3} / \mathrm{s}\right) \\
& U D_{i n h}=\text { inhalation unit } 1 \text { iter dose }(\mathrm{Sv} / \mathrm{L}) \\
& U L D_{\text {ing }}=\text { ingestion unit } 1 \text { iter dose }\left(\mathrm{Sv} \cdot \mathrm{m}^{3} / \mathrm{s} \cdot \mathrm{L}\right)
\end{aligned}
$$

For releases with a duration or exposure time less than 24 hours, the 1ight activity breathing rate of $3.3 \mathrm{E}-4 \mathrm{~m}^{3} / \mathrm{s}$ is assumed.

Toxicological exposure units were developed in WHC-SD-WM-SARR-011 in terms of a sum-of-fractions per unit release rate $(L / s)$, or per unit release $(L)$ for very short duration (puff) releases. Puff releases are defined in WHC-SD-WMSARR-011 as being releases with durations $\leq 3.5 \mathrm{~s}$ for the onsite receptor or $\leq 250 \mathrm{~s}$ for the site boundary receptor. This parameter already contains the

\begin{tabular}{|c|c|c|c|}
\hline \multirow[b]{2}{*}{ Receptor } & \multirow[b]{2}{*}{ Waste Component } & \multicolumn{2}{|c|}{ Sum of Fractions } \\
\hline & & $\begin{array}{l}\text { Continuous } \\
(\mathrm{s} / \mathrm{L})\end{array}$ & $\begin{array}{l}\text { Puff } \\
\left(L^{-1}\right)\end{array}$ \\
\hline Onsite & $\begin{array}{ll}\text { Double-Shell Liquids } \\
\text { or AWF } & \text { Solids }\end{array}$ & $\begin{array}{l}1.0 \mathrm{E}+4 \\
1.8 \mathrm{E}+4\end{array}$ & $\begin{array}{l}2.9 E+3 \\
5.2 E+3\end{array}$ \\
\hline Offsite & $\begin{array}{ll}\text { Double-Shell Liquids } \\
\text { or AWF } & \text { Solids }\end{array}$ & $\begin{array}{l}8.4 \mathrm{E}+0 \\
1.9 \mathrm{E}+2\end{array}$ & $\begin{array}{l}3.4 \mathrm{E}-2 \\
7.7 \mathrm{E}-1\end{array}$ \\
\hline
\end{tabular}
receptor $X / Q^{\prime}$ ( $1 \mathrm{~h}$ or puff) and the chemical component limits associated with a particular accident frequency. The frequency for the tank bump scenarios considered here has been designated as anticipated with a frequency range of 1 - $10^{-2} / y$. Unit release sums of fractions for DST or AWF waste given in WHCSD-WM-SARR-011 are shown in Table 2.

Table 2: Unit release toxicological sums of fractions for DST or AWF waste components for anticipated accident frequency $\left(1-10^{-2} / y\right)$ 
HNF-SD-WM-CN-098 Rev. 0

\section{Results:}

The sludge temperatures were initialized according to the best estimate profile assuming an extended loss of cooling leading to an initial tank bump (Sathyanarayana 1996). No credit was taken for condensation in the supernate layer in order to produce a bounding case. Several scenarios differing only in the vent pathway configuration were simulated. A wide open vent pathway out of the tank maximized the direct ejection of waste material, but did not maximize steam releases and releases of transportable, respirable material. The highest head space pressure reached for the most restrictive vent path assumed was about 5.0 psig.

In the case of the least restrictive vent path which produced the most violent bump and the largest amount of ejected waste material. The head space pressure reached a maximum of about $4.1 \mathrm{psig.} \mathrm{A} \mathrm{total} \mathrm{of} 9001 \mathrm{bm}$ of 1 iquid waste and $901 \mathrm{bm}$ of solids were ejected during the pressure spike along with release of about $15001 \mathrm{bm}$ of steam. Maximum flow rates were about $17501 \mathrm{bm} / \mathrm{s}$ for the liquids and about $1701 \mathrm{bm} / \mathrm{s}$ for the solids. Of the $9901 \mathrm{bm}(4.49 \mathrm{E}+5$ g) of waste material ejected, $91 \%$ was 1 iquids and $9 \%$ was solids by weight. The physical locations of the various tank openings were included in the simulation and strongly effected where the waste material came out. In this case all the waste material came out of a single vent path along with $2001 \mathrm{bm}$ of the steam. The other $1300 \mathrm{lbm}$ of steam exited via other paths and did not carry any waste material (according to the simulation).

The volume of the steam associated with the expulsion of waste material can be estimated by using the specific volume of saturated steam at 1 atmosphere as follows:

$$
\text { Steam Volume }=(200 \mathrm{lbm})\left(26.8 \mathrm{ft}^{3} / 1 \mathrm{bm}\right)\left(2.832 \mathrm{E}-2 \mathrm{~m}^{3} / \mathrm{ft}^{3}\right)=1.52 \mathrm{E}+2 \mathrm{~m}^{3}
$$

Assuming for such a short duration release that the steam explosion would initially form a cloud over the release point with the waste material suspended as an aerosol, the total aerosol loading in the cloud would then given by $(4.49 \mathrm{E}+5 \mathrm{~g}) /\left(1.52 \mathrm{E}+2 \mathrm{~m}^{3}\right)=2.96 \mathrm{E}+3 \mathrm{~g} / \mathrm{m}^{3}$. Even with some turbulent mixing with air, this far too great a load to be sustained in air for even a short time, and material would rapidly fall out of the cloud until the air loading decreased to some short-term sustainable value.

The maximum sustainable loading of an aerosol mist in air is normally assumed to be $100 \mathrm{mg} / \mathrm{m}^{3}$ (ANSI N46.1 1980). However, since the air loading here is for a very short-time transient condition until sufficient turbulent mixing with the surrounding air and enough evaporation of the water portion of the liquid release can occur, ten times this value, or $1 \mathrm{~g} / \mathrm{m}^{3}$, is assumed for conservatism. The total release which can be transported downwind is therefore $\left(1 \mathrm{~g} / \mathrm{m}^{3}\right)\left(1.52 \mathrm{E}+2 \mathrm{~m}^{3}\right)=1.52 \mathrm{E}+2 \mathrm{~g}$. This is a very small amount compared to the total material originally ejected from the tank in the simulation. Such a loading in the "pure" steam issuing from the tank could easily be considered negligible compared to the waste material directly 


\section{HNF-SD-WM-CN-098 Rev. 0}

ejected out of the tank openings (nearly all of which would end up laying on the ground around the release point).

It could, in fact, be reasonably assumed that all of the steam issuing from such an explosion would carry a transient loading of $1 \mathrm{~g} / \mathrm{m}^{3}$ of aerosol. It seems reasonable for this accident, therefore, to assume that all the transportable aerosol which could affect a downwind receptor is carried by the released steam at a transient loading of $1 \mathrm{~g} / \mathrm{m}^{3}$. The maximum steam release for any of the scenarios considered was $21001 \mathrm{bm}$ over a release duration of about 3 seconds. This scenario was chosen because it produces the greatest consequences using the methodology presented here. As before, the total volume of the steam carrying the maximum transient loading of $1 \mathrm{~g} / \mathrm{m}^{3}$ of waste material can be estimated by using the specific volume of saturated steam at 1 atmosphere as follows:

$$
\text { Steam Volume }=(21001 \mathrm{bm})\left(26.8 \mathrm{ft}^{3} / 1 \mathrm{bm}\right)\left(2.832 \mathrm{E}-2 \mathrm{~m}^{3} / \mathrm{ft}^{3}\right)=1.59 \mathrm{E}+3 \mathrm{~m}^{3}
$$

Assuming the same liquid-solid ratio by weight as in the original release for this scenario (620 1bm Tiquid and $78 \mathrm{lbm}$ solids), the net transportable releases are given by:

$$
\begin{aligned}
& \text { Liquids }=>(89 \%)(1.59 \mathrm{E}+3 \mathrm{~g})\left(1 \mathrm{E}-3 \mathrm{~L} / \mathrm{cm}^{3}\right) /\left(1.21 \mathrm{~g} / \mathrm{cm}^{3}\right)=1.17 \mathrm{E}+0 \mathrm{~L} \\
& \text { Solids } \Rightarrow(11 \%)(1.59 \mathrm{E}+3 \mathrm{~g})\left(1 \mathrm{E}-3 \mathrm{~L} / \mathrm{cm}^{3}\right) /\left(1.82 \mathrm{~g} / \mathrm{cm}^{3}\right)=9.63 \mathrm{E}-2 \mathrm{~L}
\end{aligned}
$$

This mix is conservative since evaporation of the water portion of the liquid waste during the mixing and transport process would permit more of the material dissolved in the liquid waste to remain suspended, thereby shifting the mix toward the liquid component (which has a lower ULD). Note also that the $1 \mathrm{~g} / \mathrm{m}^{3}$ initial loading includes the water portion of the liquid waste component which would rapidly evaporate during transport leaving only the dissolved solids. For this reason the usual maximum air loading of $100 \mathrm{mg} / \mathrm{m}^{3}$ at the onsite receptor cannot be used in this case to assume additional fallout. Radiological doses are then calculated according to the standard formulas discussed earlier using the ULDs in Table 1 as follows.

Onsite receptor inhalation:

$$
\begin{aligned}
& \text { Liquids } \Rightarrow(1.17 \mathrm{E}+0 \mathrm{~L})\left(3.41 \mathrm{E}-2 \mathrm{~s} / \mathrm{m}^{3}\right)\left(3.3 \mathrm{E}-4 \mathrm{~m}^{3} / \mathrm{s}\right)(1.4 \mathrm{E}+3 \mathrm{~Sv} / \mathrm{L}) \\
& =1.84 \mathrm{E}-2 \mathrm{SV}(1.84 \mathrm{E}+0 \mathrm{rem}) \\
& \text { Solids } \Rightarrow(9.63 \mathrm{E}-2 \mathrm{~L})\left(3.41 \mathrm{E}-2 \mathrm{~s} / \mathrm{m}^{3}\right)\left(3.3 \mathrm{E}-4 \mathrm{~m}^{3} / \mathrm{s}\right)(1.7 \mathrm{E}+6 \mathrm{SV} / \mathrm{L}) \\
& =1.84 \mathrm{E}+0 \text { SV }(1.84 \mathrm{E}+2 \text { rem }) \\
& \text { Total onsite dose }=\Rightarrow 1.86 \mathrm{E}+0 \text { Sv }(1.86 \mathrm{E}+2 \text { rem })
\end{aligned}
$$


Offsite receptor inhalation:

$$
\begin{aligned}
& \text { Liquids } \Rightarrow(1.17 \mathrm{E}+0 \mathrm{~L})\left(2.83 \mathrm{E}-5 \mathrm{~s} / \mathrm{m}^{3}\right)\left(3.3 \mathrm{E}-4 \mathrm{~m}^{3} / \mathrm{s}\right)(1.4 \mathrm{E}+3 \mathrm{SV} / \mathrm{L}) \\
& =1.53 \mathrm{E}-5 \mathrm{SV}(1.53 \mathrm{E}-3 \mathrm{rem}) \\
& \text { Solids }=\Rightarrow(9.63 \mathrm{E}-2 \mathrm{~L})\left(2.83 \mathrm{E}-5 \mathrm{~s} / \mathrm{m}^{3}\right)\left(3.3 \mathrm{E}-4 \mathrm{~m}^{3} / \mathrm{s}\right)(1.7 \mathrm{E}+6 \mathrm{sV} / \mathrm{L}) \\
& =1.53 \mathrm{E}-3 \mathrm{~Sv}(1.53 \mathrm{E}-1 \mathrm{rem}) \\
& \text { Total offsite inhalation dose }==>1.54 \mathrm{E}-3 \mathrm{SV}(1.54 \mathrm{E}-1 \mathrm{rem})
\end{aligned}
$$

offsite receptor ingestion:

$$
\begin{array}{r}
\text { Liquids } \Rightarrow \begin{array}{r}
(1.17 \mathrm{E}+0 \mathrm{~L})\left(2.83 \mathrm{E}-5 \mathrm{~s} / \mathrm{m}^{3}\right)\left(9.2 \mathrm{E}-2 \mathrm{SV} \cdot \mathrm{m}^{3} / \mathrm{s} \cdot \mathrm{L}\right) \\
=3.05 \mathrm{E}-6 \mathrm{~Sv}(3.05 \mathrm{E}-4 \mathrm{rem})
\end{array} \\
\text { Solids } \Rightarrow \begin{array}{r}
(9.63 \mathrm{E}-2 \mathrm{~L})\left(2.83 \mathrm{E}-5 \mathrm{~s} / \mathrm{m}^{3}\right)\left(8.1 \mathrm{E}+0 \mathrm{~Sv} \cdot \mathrm{m}^{3} / \mathrm{s} \cdot \mathrm{L}\right) \\
=2.21 \mathrm{E}-5 \mathrm{SV}(2.21 \mathrm{E}-3 \mathrm{rem})
\end{array}
\end{array}
$$

Total offsite ingestion dose $\Rightarrow 2.51 \mathrm{E}-5 \mathrm{SV}(2.51 \mathrm{E}-3 \mathrm{rem})$

Total offsite dose $=\Rightarrow 1.58 \mathrm{E}-3 \mathrm{SV}(1.58 \mathrm{E}-1 \mathrm{rem})$

Toxic exposures were calculated as previously discussed using the unit release ULDs shown in Table 2. Since the release duration is about $3 \mathrm{~s}$, puff ULDs were used.

Onsite receptor SOF:

$$
\begin{aligned}
& \text { Liquids }=\Rightarrow(1.17 \mathrm{E}+0 \mathrm{~L})\left(2.9 \mathrm{E}+3 \mathrm{~L}^{-1}\right)=3.39 \mathrm{E}+3 \\
& \text { Solids }=\Rightarrow(9.63 \mathrm{E}-2 \mathrm{~L})\left(5.2 \mathrm{E}+3 \mathrm{~L}^{-1}\right)=5.01 \mathrm{E}+2 \\
& \text { Total onsite SOF }=>3.89 \mathrm{E}+3
\end{aligned}
$$

Offsite receptor SOF:

$$
\begin{aligned}
& \text { Liquids }=\Rightarrow(1.17 \mathrm{E}+0 \mathrm{~L})\left(3.4 \mathrm{E}-2 \mathrm{~L}^{-1}\right)=3.98 \mathrm{E}-2 \\
& \text { Solids } \Rightarrow=>(9.63 \mathrm{E}-2 \mathrm{~L})\left(7.7 \mathrm{E}-1 \mathrm{~L}^{-1}\right)=7.42 \mathrm{E}-2 \\
& \text { Total onsite SOF }=>1.14 \mathrm{E}-1
\end{aligned}
$$


HNF-SD-WM-CN-098 Rev. 0

\section{Conclusions:}

The results of the unmitigated tank bump in AY-102 are summarized in Table 3 .

Table 3: Consequences of unmitigated tank bump in AY-102

\begin{tabular}{cccc} 
Hazard & Receptor & Dose/Exposure & $\begin{array}{c}\text { Evaluation Guideline } \\
\text { (Anticipated) }\end{array}$ \\
\hline \hline Radiological & $\begin{array}{l}\text { Offsite } \\
\text { Onsite }\end{array}$ & $1.6 \mathrm{mSv}$ & $1 \mathrm{mSv}$ \\
Toxicological & $\begin{array}{l}\text { Offsite } \\
\text { Onsite }\end{array}$ & $1.9 \mathrm{~Sv}$ & $5 \mathrm{mSv}$ \\
& $3.9 \mathrm{E}+3$ & 1
\end{tabular}

Note that the release contributions due to waste material initially suspended in the tank head space and on the exhaust vent HEPA filter are negligible compared to the releases from the bump itself and were not included. Note al so that the assumed initial loading of the steam plume at $1 \mathrm{~g} / \mathrm{m}^{3}$ is a conservative engineering judgement. The inital steam plume loading could be somewhat higher, which would not effect the conclusions, but there is no technical justification for assuming a lower value. 


\section{References:}

ANSI N46.1, 1980, American National Standard - Guidance for Defining SafetyRelated Features of Nuclear Fuel Cycle Facilities, American Nuclear Society, La Grange Park, Illinois.

Bander 1996, T.J. Bander, B.A. Crea, and D.M. Ogden, Tank 241-C-106 Sluicing Evaluation, WHC-SD-WM-ER-588 Rev 1, June 1996.

Cowley 1996, W.L. Cowley, Development of Radiological Concentrations and Unit Liter Doses for TWRS FSAR Radiological Consequence Calculations, WHC-SDWM-SARR-037 Rev 0, April 1996.

Sathyanarayana 1996, K. Sathyanarayana, Evaluation of Potential and Consequences of Steam Bump in High Heat Waste Tanks and Assessment and Validation of GOTH Computer Code, WHC-SD-WM-CN-022 Rev 0, July 1996.

Sathyanarayana 1997, K. Sathyanarayana, Project $W-320$ Thermal Evaluation, HNF-SD-W320-ER-002 Rev 0, January 1997.

Van Keuren 1996a, J.C. Van Keuren, Tank Waste Compositions and Atmospheric Dispersion Coefficients for use in Safety Analysis Consequence Assessments, WHC-SD-WM-SARR-0I6 Rev 2, July 1996.

Van Keuren 1996b, J.C. Keuren, J.S. Davis, and M.L. Dentler, Toxic Chemical Considerations for Tank Farm Releases, WHC-SD-WM-SARR-011 Rev 2, August 1996. 
HNF-SD-WM-CN-098 Rev. 0

CHECKLIST FOR PEER REVIEW

Document Reviewed: CONSEQUENCES OF A POSTULATED TANK BUMP RELATED TO

PROJECT W-320, D.A. Himes, 3/18/97

Scope of Review: entire document

$\frac{\text { Yes No NA }}{\text { X] [ ] }]}$ *

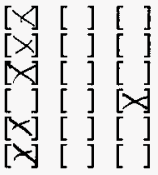

[ ] [ ] $\mathbb{X}]$

[x] [ ] [ ]

[X] [ ] [ ]

[ ] $\left[\begin{array}{ll} & x\end{array}\right]$

[][]$[X]$

$x][$ ] [ ]

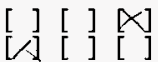

[X] [ ] [ ]

[ ] [ ] $\ltimes]$

[ ] $[X]$ *

Previous reviews complete and cover analysis, up to scope of this review, with no gaps.

Problem completely defined.

Accident scenarios developed in a clear and logical manner.

Necessary assumptions explicitly stated and supported.

Computer codes and data files documented.

Data used in calculations explicitly stated in document.

Data checked for consistency with original source information as applicable.

Mathematical derivations checked including dimensional consistency of results.

Models appropriate and used within range of validity or use outside range of established validity justified.

Hand calculations checked for errors. Spreadsheet results should be treated exactly the same as hand calculations.

Software input correct and consistent with document reviewed.

Software output consistent with input and with results reported in document reviewed.

Limits/criteria/guidelines applied to analysis results are

appropriate and referenced. Limits/criteria/guidelines checked against references.

Safety margins consistent with good engineering practices.

Conclusions consistent with analytical results and applicable

limits.

Results and conclusions address all points required in the problem statement.

Format consistent with appropriate NRC Regulatory Guide or other standards

\section{[×] [ ] [ ] Document approved.}

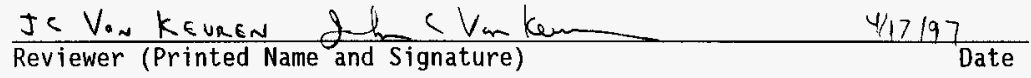

* Any calculations, comments, or notes generated as part of this review should be signed, dated and attached to this checklist. Such material should be labeled and recorded in such a manner as to be intelligible to a technically qualified third party. 
HNF-SD-WM-CN-098 Rev. 0

\section{HEDOP REVIEW CHECKLIST \\ for}

Radiological and Nonradiological Release Calculations

Document reviewed (include title or description of calculation, document number, author, and date, as applicable):

Consequences of a Postulated Tank Bump Related to Project W-320, HNF-SD-WM-CN-098, Rev. 0, D. A. Himes

Submitted by: D. A. Himes Date Submitted: 04/30/97

Scope of Review: Entire document

YES NO* N/A

[ $]$ [ ] [ ] 1. A detailed technical review and approval of the environmental transport and dose calculation portion of the analysis has been performed and documented.

[J] [ ] [ ] 2. Detailed technical review(s) and approval(s) of scenario and release determinations have been performed and documented.

[]$\quad[][[/]$ 3. HEDOP-approved code $(s)$ were used.

$[\sigma][]$ [ ] 4. Receptor locations were selected according to HEDOP recommendations.

[C] [ ] [ ] 5. All applicable environmental pathways and code options were

[V] [ ] [ ] 6. Hanford site data were used.

[] [ ] [ [ 7 7. Model adjustments external to the computer program were justified and performed correctly.

[ $]$ [ ] [ ] 8. The analysis is consistent with HEDOP recommendations.

[ ] [ $[$ 9. Supporting notes, calculations, comments, comment resolutions, or other information is attached. (Use the "Page 1 of $X$ " page numbering format and sign and date each added page.)

[C] [ ] 10. Approval is granted on behalf of the Hanford Environmental Dose Overview Pane1.

* All "NO" responses must be explained and use of nonstandard methods justified.

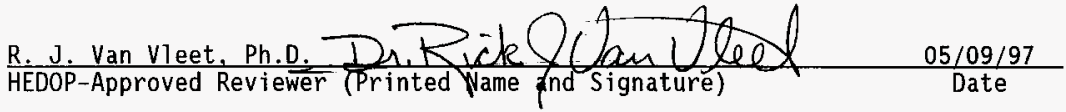

COMMENTS (add additional signed and dated pages if necessary): 


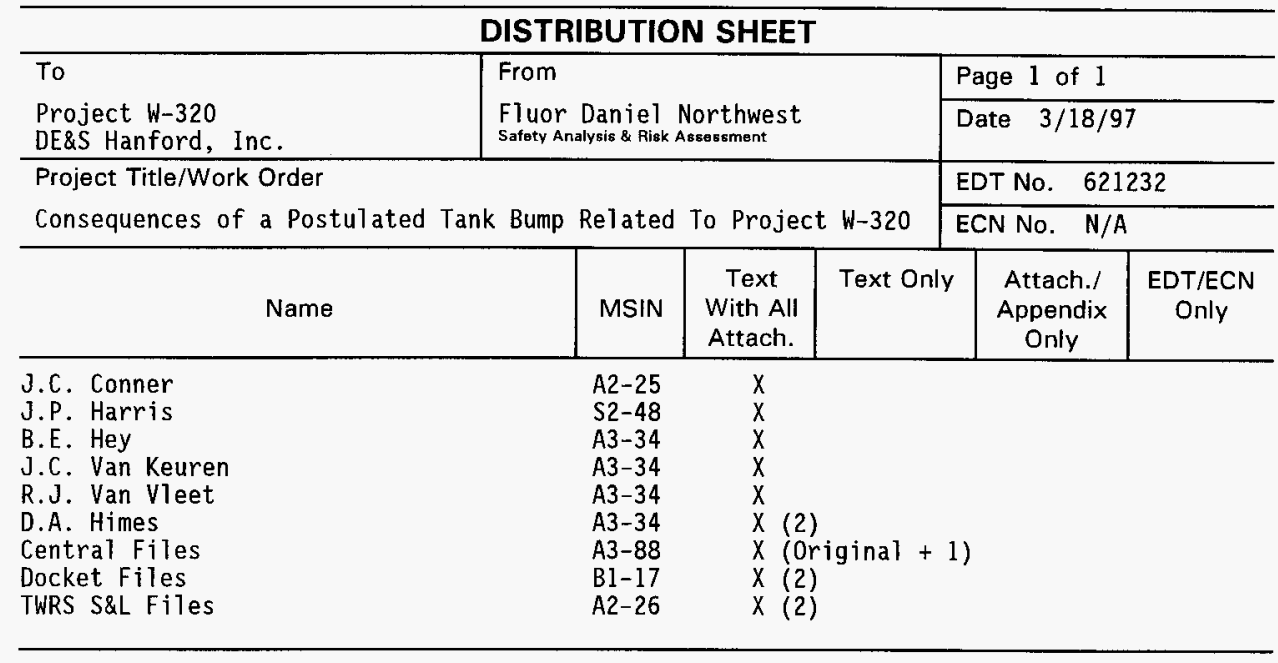

